\title{
Effect of feeding melatonin to red deer (Cervus elaphus) on the onset of the breeding season
}

\author{
Clare L. Adam and T. Atkinson \\ Rowett Research Institute, Bucksburn, Aberdeen AB2 9SB, U.K.
}

\begin{abstract}
Summary. Four non-lactating red deer hinds kept in natural light were each given orally $5 \mathrm{mg}$ melatonin daily in the afternoon from 1 June to 5 October. The time difference between melatonin administration and sunset was 5.5-6 h until the end of August, thereafter gradually decreasing to $3.5 \mathrm{~h}$. Onset of oestrous cyclicity occurred in late August and early September, $2-8$ weeks in advance of control hinds. A stag given $10 \mathrm{mg}$ melatonin daily shed the antler velvet on $18 \mathrm{July}, 4$ weeks earlier than untreated stags, and started rutting behaviour in July-August, 2 months before the usual time.
\end{abstract}

\section{Introduction}

Sheep are stimulated to breed by short daylength and it is thought that the pineal hormone melatonin, plasma concentrations of which are elevated during the hours of darkness (Arendt, Symons \& Laud, 1981 ; Lincoln, Almeida \& Arendt, 1981), is the primary mediator of the stimulus (Bittman, Dempsey \& Karsch, 1983). The nocturnal rise in plasma melatonin concentrations is readily mimicked by oral administration of the hormone during the hours of daylight, with elevated values being sustained for periods exceeding $7 \mathrm{~h}$ (Kennaway \& Seamark, 1980). Feeding melatonin to ewes in the afternoon can therefore signal shortening of daylength by producing high plasma concentrations which are sustained until endogenous secretion of the hormone is initiated by the onset of darkness. Melatonin given by this method over a period of several weeks has been shown to induce the early onset of the breeding season in ewes (Kennaway, Gilmore \& Seamark, 1982; Arendt, Symons, Laud \& Pryde, 1983) and to advance the seasonal cycle in male white-tailed deer (Bubenik, 1983). The present study was undertaken to see whether exogenous melatonin could advance the onset of the breeding season in another short-day breeder, the red deer (Cervus elaphus).

\section{Materials and Methods}

Two groups (A and B) of 4 non-pregnant, non-lactating red deer hinds, average live weight $80 \mathrm{~kg}$ and age 2-3 years, and one 4-year-old stag, weighing about $150 \mathrm{~kg}$, were penned indoors separately but within the range of sight, smell and sound of each other. The building had many skylights, providing natural daylight conditions (in Aberdeen, $57^{\circ} 10^{\prime} \mathrm{N}$ ), and no artificial lighting was used. All deer received a pelleted concentrate ration, in equal proportions twice daily, with hay and dried grass to appetite. From 1 June 1983 (Day 1) until 5 October, immediately before the afternoon feed, each hind in Group A received daily $5 \mathrm{mg}$ melatonin adsorbed onto a feed pellet, and Group B hinds, as controls, were given the feed unsupplemented. The stag received $10 \mathrm{mg}$ melatonin daily by the same method until removed from the building in full rut on 24 August and replaced by an untreated, non-rutting stag.

The melatonin was given at $16: 00 \mathrm{~h}$ from 1 June to $27 \mathrm{July}$, i.e. $5 \cdot 5-6 \mathrm{~h}$ before sunset and about $12.5 \mathrm{~h}$ before sunrise. From 28 July to 10 August, the time of administration was advanced by 4-5 min daily to remain at $15: 00 \mathrm{~h}$ thereafter, thus sustaining until the end of August the $5 \cdot 5-6 \mathrm{~h}$ time 
interval to sunset. Subsequently the time interval from administration to sunset gradually decreased to $3.5 \mathrm{~h}$ by 5 October, and to sunrise gradually increased to $16.5 \mathrm{~h}$.

Starting on 1 June, blood samples were collected from the hinds by jugular venepuncture into heparinized tubes at 09:00 h once weekly for the first 4 weeks, and thereafter on Monday, Wednesday and Friday of each week, and the plasma was stored at $-20^{\circ} \mathrm{C}$ until analysed for progesterone. On 5 October all 8 hinds and the stag were turned outside in one group and blood sampling continued until 10 November.

Progesterone concentrations in plasma were determined by a modification of the radioimmunoassay method of Henricks, Dickey \& Hill (1971). The antiserum (HP/S/53-II C from Guildhay Antisera, University of Surrey, England) and the cross-reactions, as stated by the suppliers, were $0.3 \%$ with 17 -hydroxyprogesterone, $0.8 \%$ with corticosterone, $0.9 \%$ with deoxycorticosterone and negligible for other steroids. To each tube, $0.1 \mathrm{ml}$ of a $1: 12500$ dilution of the antiserum was added together with $80 \mathrm{pg}(0.02 \mu \mathrm{Ci})$ of tritiated progesterone (TRK 413, from Amersham International, Bucks, U.K.). Separation of the bound and free fractions was by dextran-coated charcoal. Intraand inter-assay coefficients of variation were 9 and $13 \%$ respectively. The sensitivity of the assay was $0.2 \mathrm{ng} / \mathrm{ml}$.

\section{Results}

The treated stag showed reduced antler growth and early antler mineralization, with the velvet being shed on 18 July (Day 48 of the experiment), 4 weeks earlier than for untreated stags in the field. The antlers were removed on 21 July and the stag started to display characteristic rutting
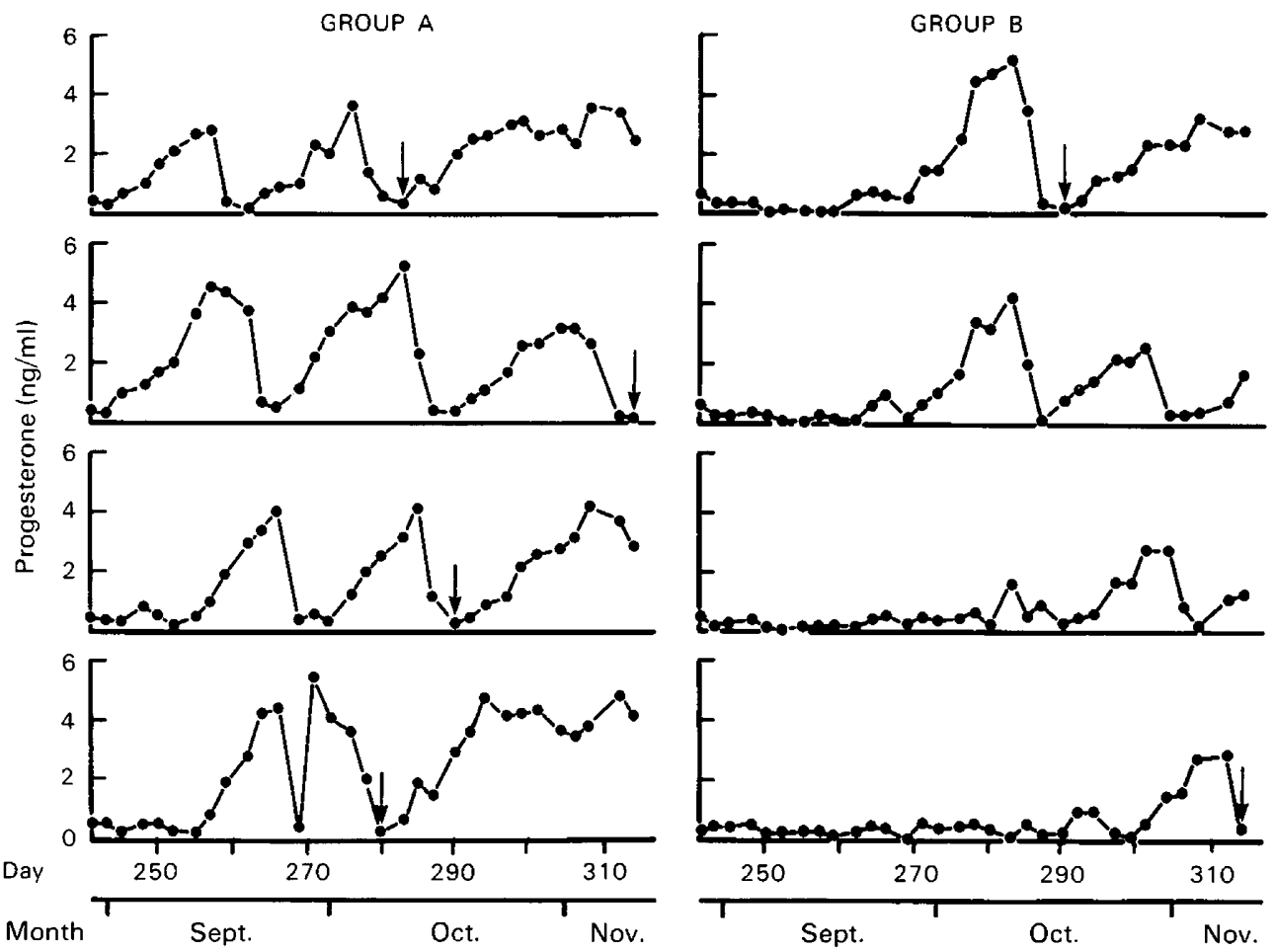

Text-fig. 1. Plasma progesterone profiles of melatonin-treated hinds (Group A) and untreated controls (Group B) from 29 August (Day 241) to 10 November (Day 314). A stag had access to the hinds from 5 October (Day 278) and an arrow denotes successful mating. 
behaviour of roaring and aggression, 6-8 weeks in advance of untreated stags and earlier than the rut has ever occurred in the Rowett herd over several previous years. The treated stag was moved outdoors on 24 August, having become difficult to manage indoors, and he continued rutting until the end of the normal breeding season in November.

For the first 13 weeks of the experiment, plasma progesterone concentrations remained below 1 $\mathrm{ng} / \mathrm{ml}$ (average $0.4 \mathrm{ng} / \mathrm{ml}$ ) for all hinds in both groups; thereafter, individual progesterone profiles from 29 August to 10 November were as shown in Text-fig. 1. The onset of the breeding season was taken as the first day to be followed by a clear increase in plasma progesterone concentration sustained above $1 \mathrm{ng} / \mathrm{ml}$ for a period equivalent to the luteal phase of a normal oestrous cycle (C. $\mathrm{L}$. Adam, unpublished observations), followed by a drop in plasma progesterone below $1 \mathrm{ng} / \mathrm{ml}$ indicative of the second oestrus and ovulation. The days of the year were numbered consecutively from 1 January for statistical purposes, and the mean \pm s.e.m. time of onset of oestrus was earlier for all treated hinds (Group A), $248 \pm 2$ days ( 5 September), than for untreated hinds (Group B), $282 \pm 8$ days ( 9 October) $(P<0.005$; Student's $t$ test). Although a stag was present indoors, he remained in a separate pen and matings could not occur until the deer were turned outdoors on 5 October (Day 278). At this date, when melatonin feeding was stopped, all treated hinds were in their second oestrous cycle whereas only 2 of the controls had started their first cycle. The time of onset of oestrus of the controls was consistent with data from other red deer hinds kept outdoors. Successful mating was judged to have occurred when oestrus was followed by consistently high ( $>1$ $\mathrm{ng} / \mathrm{ml}$ ) plasma progesterone values.

\section{Discussion}

The onset of seasonal oestrous cyclicity in melatonin-treated hinds was earlier than that for control hinds by 2-8 weeks, a similar advance to that reported for ewes by Arendt et al. (1983). Unlike the sheep trial, the present experiment included the presence of a male in the building at all times (treated or untreated), thus allowing the possibility of pheromonal effects, but equally on both groups of hinds. However, oestrus was not advanced in the control hinds compared with hinds outdoors, and the earlier onset of oestrus in the treated hinds was evidently induced by the exogenous melatonin. Not only did these hinds show oestrus at a time when the controls were in natural seasonal anoestrus, but once started they remained cyclic throughout the normal breeding season until successfully mated. It remains to be tested whether the first melatonin-induced cycles are fertile.

The normal pattern of antler cleaning and onset of rutting behaviour in red deer stags is very strictly seasonal (e.g. Clutton-Brock, Guinness \& Albon, 1982). The effect of melatonin feeding on the stag in the present trial was dramatic, with early visible changes in antler development, as reported for white-tailed deer (Bubenik, 1983). Rutting behaviour began 6-8 weeks ahead of normal and, as with oestrus in the hinds, once started, it continued throughout the normal season.

In the present study, the induction of natural breeding patterns in male and female deer by oral administration of melatonin indicates that melatonin could be the natural mediator of the reproductive response to photoperiod in red deer as it appears to be in the ewe (Bittman et al., 1983). The time interval between melatonin administration and sunset remained well within $7-8 \mathrm{~h}$, this being the duration for which melatonin-fed sheep have sustained high plasma melatonin values (Kennaway \& Seamark, 1980; Kennaway et al., 1982; Arendt et al., 1983). Although plasma melatonin profiles were not determined, the positive short-day response shown by the deer in the present trial indicated that plasma concentrations were indeed elevated shortly after oral administration and sustained until nightfall when endogenous melatonin secretion increased. The initial timing of the melatonin dose caused a very abrupt increase in the 'dark' period, from about 6.5 to $12.5 \mathrm{~h}$ and further increases during the experiment were relatively slight (i.e. up to a maximum of $16.5 \mathrm{~h}$ in 4 months). Furthermore, as indicated by the early response shown by the 
stag, the melatonin treatment seems likely to have initiated some changes early on in the dosing programme, and the shift in dose-time from 16:00 $\mathrm{h}$ to 15:00 h may not have been important. Indeed, the precise time interval from melatonin application to sunset may have been less critical than the total daily duration of high circulating plasma melatonin concentrations. This would be in agreement with at least one hypothesis explaining the action of melatonin (discussed by Lincoln, 1983) which postulates that a short-day response is elicited if the blood levels of melatonin are continuously elevated for more than $12 \mathrm{~h}$ every day for several weeks.

The present trial shows clearly that daily oral melatonin administration can advance the breeding season of red deer and, as melatonin feeding should be possible under field conditions, the technique has potential for use in the agricultural industry.

We thank Carol E. Moir and Mr H. MacAlister for technical assistance.

\section{References}

Arendt, J., Symons, A.M. \& Laud, C.A. (1981) Pineal function in the sheep: evidence for a possible mechanism mediating seasonal reproductive activity. Experientia 37, 584-586.

Arendt, J., Symons, A.M., Laud, C.A. \& Pryde, S.J. (1983) Melatonin can induce early onset of the breeding season in ewes. J. Endocr. 97, 395-400.

Bittman, E.L., Dempsey, R.J. \& Karsch, F.J. (1983) Pineal melatonin secretion drives the reproductive response to daylength in the ewe. Endocrinology 113, 2276-2283.

Bubenik, G.A. (1983) Shift of seasonal cycle in whitetailed deer by oral administration of melatonin. $J$. exp. Zool. 225, 155-156.

Clutton-Brock, T.H., Guinness, F.E. \& Albon, S.D. (1982) Red Deer. Behaviour and Ecology of two sexes. The University of Chicago Press.
Henricks, D.M., Dickey, J.F. \& Hill, J.R. (1971) Plasma estrogen and progesterone levels in cows prior to and during estrus. Endocrinology 89, 1350-1355.

Kennaway, D.J. \& Seamark, R.F. (1980) Circulating levels of melatonin following its oral administration or subcutaneous injection in sheep and goats. Aust. J. biol. Sci. 33, 349-353.

Kennaway, D.J., Gilmore, T.A. \& Seamark, R.F. (1982) Effect of melatonin feeding on serum prolactin and gonadotropin levels and the onset of seasonal estrous cyclicity in sheep. Endocrinology 110, 1766-1772.

Lincoln, G.A. (1983) Melatonin as a seasonal time-cue: a commercial story. Nature, Lond. 302, 755.

Lincoln, G.A., Almeida, O.F.X. \& Arendt, J. (1981) Role of melatonin and circadian rhythms in seasonal reproduction. J. Reprod. Fert., Suppl. 30, 23-31. 